\title{
HUKUM PELAKSANAAN SALAT TARAWIH DI RUMAH KARENA WABAH DAN MEMBACA AL-QUR'AN MELALUI MUSHAF DAN HP KETIKA SALAT
}

\section{Aswanto Muhammad Takwi Hede}

Sekolah Tinggi Ilmu Islam dan Bahasa Arab (STIBA) Makassar

Email: asw_mt@yahoo.com

\section{Rachmat bin Badani Tempo}

Sekolah Tinggi Ilmu Islam dan Bahasa Arab (STIBA) Makassar

Email: rachmatbadani16@gmail.com

\section{Irsyad Rafi}

Sekolah Tinggi Ilmu Islam dan Bahasa Arab (STIBA) Makassar

Email: irsyadrafi@stiba.ac.id

Keywords:

Tarawih, home, mushaf, mobile phone, Covid-19
This study aimed to provide explanation and overview related to the law of tarawih prayers at home in an pandemic situation (Covid-19), the law of performing prayers at home with the intention of participating in congregation in the mosque, and the law of reciting the mushaf or mobile phones while leading tarawih prayer. This research used a descriptive qualitative approach using content analysis techniques and library research. The results show that if in an area where the potential for outbreaks of the covid-19 outbreak is high and there has been an appeal from the local government and scholars (MUI), then in these state the more important thing is to perform tarawih prayers at home, both congregationally with family members, and this is the preferred, or individually; (2) invalidity of the prayers of a person who follows the congregational prayers outside the mosque building, where the scholars agree that he must go to the mosque; and (3) it is permissible to recite from the mushaf in the sunnah (optional) prayers, such as tarawih prayer for imams who do not memorize the Koran. As for the obligatory prayers, it is disliked because there is no need to do so. This law also applies to someone who wants to recite the Koran with the software of Koran on mobile phones.

Kata kunci: $\quad$ ABSTRAK

Tarawih, rumah, mushaf, Penelitian ini bertujuan untuk memberikan penjelasan dan HP, Covid-19 gambaran terkait hukum pelaksanaan salat tarawih di rumah dalam kondisi wabah (Covid-19), hukum melaksanakan salat di rumah dengan niat ikut berjemaah di masjid dan hukum membaca mushaf atau HP ketika menjadi imam salat tarawih. Penelitian 
ini menggunakan metode pendekatan kualitatif deskriptif dengan menggunakan teknik content analysis (analisis isi) dan riset kepustakaan (library research). Hasil menunjukkan bahwa: jika berada di suatu daerah yang potensi penyebaran terjangkitnya wabah Covid-19 tinggi dan telah ada imbauan dari pemerintah dan MUI setempat, maka dalam kondisi seperti ini yang lebih utama adalah melaksanakan salat tarawih di rumah, baik itu dengan berjemaah bersama dengan anggota keluarga, dan itu yang utama, atau dikerjakan secara sendiri-sendiri; (2) tidak sahnya salat seseorang yang bermakmum mengikuti imam salat jemaah di luar bangunan masjid, dimana para ulama bersepakat bahwa ia harus mendatangi masjid; dan (3) bolehnya membaca dari mushaf dalam salat sunah, seperti salat tarawih bagi imam yang tidak menghafal Al-Qur'an. Adapun dalam salat wajib maka hukumnya dimakruhkan karena tidak adanya hajat untuk hal tersebut. Hukum ini juga berlaku bagi seseorang yang hendak membaca Al-Qur'an dengan aplikasi Al-Qur'an di HP.

\section{PENDAHULUAN}

Salat tarawih adalah salat sunah yang sangat dianjurkan dikerjakan pada setiap malam di bulan suci Ramadan. Namun di hari-hari ini, umat manusia sedang menghadapi wabah yang telah menjadi pandemi global di seluruh dunia. Dengan adanya imbauan social distancing dari pemerintah dan fatwa ulama tentang peniadaan salat Jumat, salat berjemaah di masjid untuk sementara waktu, menjadi dilema bagian sebagian kaum muslimin terkait pelaksanaan salat tarawih di bulan Ramadhan. Sebagian masyarakat yang tidak memahami maslahat yang ada, akhirnya tidak menghiraukan arahan pemerintah, para ulama dan ahli medis, dan tetap bersikukuh melaksanakan ibadah secara berjemaah di masjid.

Pertanyaan yang muncul kemudian adalah bagaimana hukum dan anjuran pelaksanaan salat tarawih di rumah dalam kondisi wabah (Covid-19) seperti saat ini? Jika misalnya dianjurkan untuk melaksanakan shalat tarawih di rumah, bagaimana pula hukum melaksanakan salat di rumah dengan niat ikut berjemaah di masjid seperti melalui pengeras suara masjid karena rumah bersebelahan dengan masjid? Selanjutnya, mengingat bahwa sebagian masyarakat belum terbiasa menjadi imam salat tawarih, pertanyaan yang muncul adalah bagaimana hukum membaca mushaf atau HP ketika menjadi imam salat tarawih di rumah?

Oleh karena itu, penelitian ini dilakukan dengan tujuan untuk memberikan penjelasan dan gambaran terkait hukum pelaksanaan salat tarawih di rumah dalam kondisi wabah (Covid-19), hukum melaksanakan salat di rumah dengan niat ikut berjemaah di masjid dan hukum membaca mushaf atau HP ketika menjadi imam salat tarawih.

Penelitian ini menggunakan metode pendekatan kualitatif deskriptif merupakan upaya memahami berbagai konsep yang ditemukan dalam proses 
Website: https://journal.stiba.ac.id

penelitian, dengan menggunakan teknik content analysis (analisis isi) dan riset kepustakaan (library research). Teknik content analysis merupakan metode penelitian yang digunakan untuk mengetahui simpulan dari sebuah teks. Atau dengan kata lain, analisis isi merupakan metode penelitian yang ingin mengungkap gagasan penulis yang termanifestasi maupun yang laten. Sedangkan riset kepustakaan (library research) pada penelitian ini menggunakan jenis dan sumber data sekunder yang diperoleh dari hasil penelitian, artikel dan buku-buku referensi yang membahas topik yang berkaitan dengan fokus penelitian. ${ }^{1}$

\section{PEMBAHASAN}

\section{Hukum Shalat Tarawih di Rumah Saat Wabah}

Suatu salat yang hukumnya sunah dan tidak wajib pada dasarnya dianjurkan dilaksanakan di rumah sebagaimana dalam hadis Zaid bin Tsabit radhiyallahu 'anhu bahwa Rasulullah shallallahu 'alaihi wasallam bersabda:

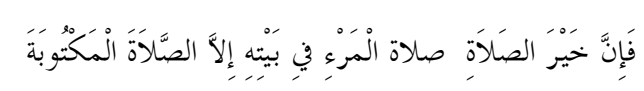

Artinya:

"Sesungguhnya sebaik-baik salat adalah salatnya seseorang di rumahnya, kecuali salat wajib/fardu." 2

Ibnu Hajar berkata:

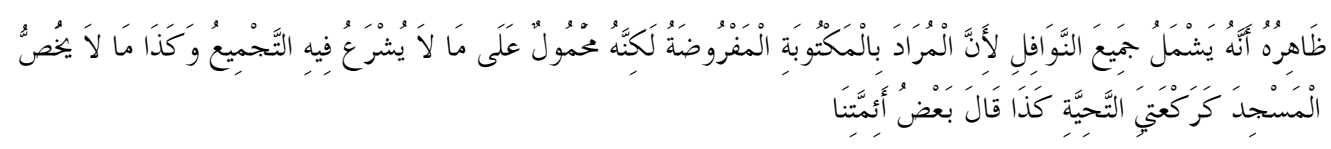

Artinya:

"Nampaknya bahwa hal itu mencakup seluruh salat sunah, karena yang dimaksud dengan Salat wajib di sini adalah salat fardu, namun hal itu dimaksudkan pada salat-salat sunah yang tidak disyariatkan padanya berjemaah, demikian juga salat sunah yang tidak dikhususkan dilaksanakan di masjid seperti dua rakaat salat tahiyyatul masjid, demikian pendapat sebagian imam (mazhab) kami."3

${ }^{1}$ Azwar Iskandar dan Khaerul Aqbar, Kedudukan Ilmu Ekonomi Islam di Antara Ilmu Ekonomi dan Fikih Muamalah: Analisis Problematika Epistemologis, Nukhbatul 'Ulum: Jurnal Bidang Kajian Islam, Vol. 5, No. 2 (2019), h. 88-105. https://journal.stiba.ac.id/index.php/nukhbah/article/view/77.

2 Muhammad bin Ismail al-Bukhari, Sahih Bukhari, Juz VIII (Cet. I; Dar Tauq al-Najat, 1422 H) h. 6113, dan Muslim bin Hajjaj, Sahih Muslim, Juz I (Beirut: Dar Ihya al-Turats) h. 539.

${ }^{3}$ Ahmad bin Ali bin Hajar, Fathul Bari Syarah Sahih Bukhari, Juz II (Beirut: Dar alMa'rifah, 1379 H) h. 215. 
Walaupun demikian, salat sunat pun juga boleh dilaksanakan di masjid, sebagaimana Rasulullah shallallahu 'alaihi wasallam pernah melaksanakan salat rawatib di masjid. Ibnu Umar radhiyallahu 'anhuma berkata:

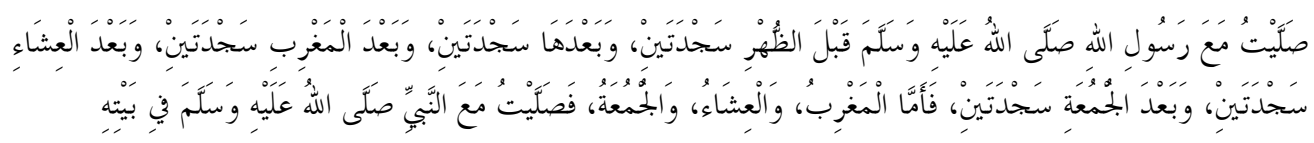

Artinya:

"Aku pernah salat bersama Rasulullah shallallahu 'alaihi wasallam dua rakaat sebelum Zuhur dan dua rakaat setelahnya, dua rakaat setelah Magrib, dua rakaat setelah Isya, dan dua rakaat setelah salat Jumat. Adapun (sunah) Maghrib, Isya, dan Jumat, aku salat bersama Nabi shallallahu 'alaihi wasallam di rumahnya."

Nampaknya, beliau laksanakan salat sunah Zuhur di masjid. Imam Nawawi berkata:

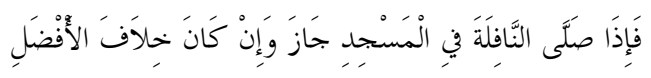

Artinya:

"Jika ia salat sunah di masjid maka hukumnya boleh, walaupun menyelisihi yang utama."5

Khusus salat tarawih (qiyam ramadhan), terdapat perbedaan pendapat di kalangan ulama, apakah lebih utama dilaksanakan di rumah secara sendiri-sendiri atau dilaksanakan secara berjemaah di masjid. Mayoritas ulama berpendapat bahwa salat tarawih di masjid secara berjemaah lebih utama daripada salat sendirian di rumah. ${ }^{6}$

Dasarnya adalah contoh dari Rasulullah shallallahu 'alaihi wasallam sebagaimana yang disebutkan oleh Abu Dzar dan Aisyah radhiyallahu 'anhuma bahwa Rasulullah shallallahu 'alaihi wassalam pernah di bulan Ramadan melaksanakan salat berjemaah bersama dengan para sahabatnya di mesjid, lalu beliau bersabda:

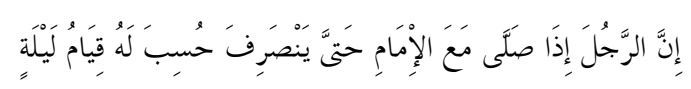

${ }^{4}$ Muslim bin Hajjaj, Sahih Muslim, Juz I, h. 504.

${ }^{5}$ Yahya bin Syaraf al-Nawawi, al-Majmu’ Syarah al-Muhadzdzab, Juz III (Dar al-Fikr) h. 492.

${ }^{6}$ Yahya bin Syaraf al-Nawawi, al-Majmu' Syarah al-Muhadzdzab, Juz IV (Dar al-Fikr) h. 35, dan Abdullah bin Ahmad bin Quddamah, al-Mugni, Juz II (Kairo: Maktabah al-Qahirah, 1388 H) h. 123. 
Artinya:

"Sungguh seseorang jika salat bersama dengan imam hingga selesai maka dihitung baginya salat semalam (penuh)."7

Demikian juga ijmak (kesepakatan) para sahabat Rasulullah shallallahu 'alaihi wasallam dalam melaksanakan salat tarawih secara berjemaah di masjid, sebagaimana yang telah dilakukan oleh Umar bin Khattab radhiyallahu 'anhu demikian juga Ali bin Abi Thalib radhiyallahu 'anhu, dan hal ini dipersaksikan oleh para sahabat Rasulullah shallallahu 'alaihi wasallam yang ada pada saat itu serta mereka melaksanakannya secara berjemaah di masjid-masjid. ${ }^{8}$

Sebagian ulama, di antaranya: Imam Malik dan sebagian pengikut Imam Syafi'i berpendapat bahwa yang paling utama adalah melaksanakan salat tarawih secara sendiri-sendiri di rumah. ${ }^{9}$ Dasarnya adalah hadis Zaid bin Tsabit radhiyallahu anhu di atas. Di antara sahabat ada yang lebih memilih salat tarawih di rumah, khususnya bagi penghafal Al-Qur'an dan memiliki bacaan yang baik, sebagaimana diriwayatkan dari Ibnu Umar radhiyallahu 'anhuma dan diikuti oleh beberapa orang tabiin. ${ }^{10}$

Terlepas manakah yang lebih utama apakah salat berjemaah di masjid atau salat di rumah, yang jelas bahwasanya Rasulullah shallallahu 'alaihi wasallam pernah melaksanakannya sendiri di rumah dan pernah juga berjemaah bersama dengan para sahabatnya di masjid. Hal ini menunjukkan bahwa keduaduanya boleh dilakukan, baik berjemaah di masjid atau berjemaah di rumah atau salat sendiri-sendiri di rumah. Kendati demikian, jika berada di suatu daerah yang potensi penyebaran terjangkitnya wabah Covid-19 tinggi dan telah ada imbauan dari pemerintah dan MUI setempat untuk melaksanakan salat tarawih di rumah masing-masing maka dalam kondisi seperti ini yang lebih utama adalah melaksanakan salat tarawih di rumah, baik itu dengan berjemaah bersama dengan anggota keluarga, dan itu yang utama, atau dikerjakan secara sendiri-sendiri.

Kita berharap kita tetap mendapatkan pahala berjemaah dengan sempurna, sebagaimana hadis yang diriwayatkan Abu Musa radhiyallahu 'anhu, Rasulullah shallallahu 'alaihi wasallam bersabda:

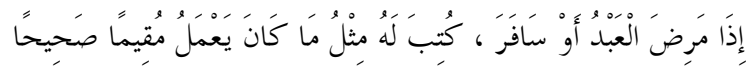

Artinya:

\footnotetext{
${ }^{7}$ Sulaiman bin al-Asy'ats bin Ishaq, Sunan Abi Dawud, Juz II (Cet. I; Dar al-Risalah al'Alamiyah, 1430 H) h. 525.

${ }^{8}$ Abdullah bin Ahmad bin Quddamah, al-Mugni, Juz II, h. 124.

${ }^{9}$ Abdullah bin Ahmad bin Quddamah, al-Mugni, Juz II, h. 124.

${ }^{10}$ Abu Bakar bin Abi Syaibah, al-Mushannaf, Juz II (Cet. I; Riyadh: Maktabah al-Rusyd, 1409 H) h. 166.
} 
"Jika seorang hamba sakit atau melakukan safar (perjalanan jauh), maka dicatat baginya pahala sebagaimana kebiasaan dia ketika mukim dan ketika sehat."11

Dari hadis itu, Ibnu Hajar al-Asqalani mengatakan:

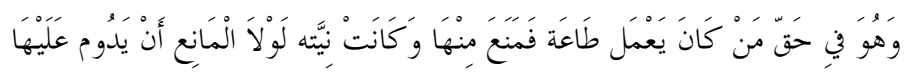

Artinya:

"Hadis di atas berlaku untuk orang yang ingin melakukan ketaatan lantas terhalang dari melakukannya. Padahal ia sudah punya niatan kalau tidak ada yang menghalangi, amalan tersebut akan dijaganya secara rutin."12

\section{Salat di Rumah dengan Niat Ikut Berjemaah di Masjid}

Para ulama telah membahas permasalahan yang erat kaitannya dengan ibadah salat jemaah dimasjid. Mulai dari pembahasan mengenai hukum wajibnya salat berjemaah, keutamaannya, hingga pada pembahasan sah tidaknya seorang makmum ber-iqtida (mengikuti) imam dalam salat jemaah di luar wilayah masjid.

Berikut penjelasan singkat pendapat mazhab mengenai hal-hal yang menjadi syarat penentu sah tidaknya salat makmum yang ber-iqtida (mengikuti) imam dalam salat jemaah di luar wilayah masjid:

1) Dalam mazhab Hanafi dipersyaratkan dalam salat jemaah, bersatunya tempat salat imam dan makmum serta tidak dipisahkan oleh apapun. Sebab berpisahnya tempat imam dan makmum tidak bisa dianggap bahwa makmum mengikuti salat jemaah, karena bersatunya tempat merupakan kelaziman dalam berjemaah. ${ }^{13}$

2) Dalam mazhab Maliki dibolehkan seorang makmum mengikuti imam, walaupun berada di tempat terpisah. Tapi dengan syarat bahwa makmum mengetahui dengan pasti salat imam yakni menyaksikannya melalui jendela rumahnya, atau sekedar mendengar dengan jelas dan bisa mengikuti jalannya salat. Mereka berdalilkan salatnya istri-istri nabi di rumah/kamar mereka. Akan tetapi dipersyaratkan bukan salat Jumat. ${ }^{14}$

\footnotetext{
${ }^{11}$ Muhammad bin Ismail al-Bukhari, Sahih Bukhari, Juz IV, h. 57.

${ }^{12}$ Ahmad bin Ali bin Hajar, Fathul Bari Syarah Sahih Bukhari, Juz VI, h. 136.

${ }^{13}$ Abu Bakar bin Mas'ud bin Ahmad al-Kasani, Badāi' al-Sanāi' fi Tartib al-Syarāi', Juz 1, (Beirut: Dar Kutub Ilmiyah, 1986), h. 145-146.

${ }^{14}$ Malik bin Anas, Al-Mudawwanah al-Kubra, Juz I (Cet. I; Beirut: Dar Kutub Ilmiyah, 1994), h. 175-176.
} 
3) Dalam mazhab Syafi'i dipersyaratkan sahnya salat berjemaah dengan tiga syarat: mengetahui salat imam (melihat atau mendengar imam atau makmum yang berada dibelakang imam); kedua, dekat dengan jemaah maksimal 300 hasta; ketiga, tidak ada penghalang yang membatasi. ${ }^{15}$

4) Dalam mazhab Hambali mempersyaratkan makmum bisa melihat dengan jelas imam atau jemaah dibelakang imam serta memungkinkan baginya untuk mengikut imam dalam salat. Jika makmum sama sekali tidak bisa melihat dengan jelas imam atau jemaah dibelakangnya, maka salatnya tidak sah, walaupun dia mendengar takbirnya imam. ${ }^{16}$

Para ulama mazhab dalam masalah ini walau berbeda dalam redaksi pendalilan serta syarat-syarat yang menunjukkan tidak sahnya seorang bermakmum di luar bangunan masjid, mereka bersepakat bahwa tidak sah salat seorang yang bertetangga dengan masjid kecuali dia harus mendatangi masjid.

Masalah serupa juga pernah dijawab oleh komisi Fatwa Lajnah Daimah Kerajaan Arab Saudi:

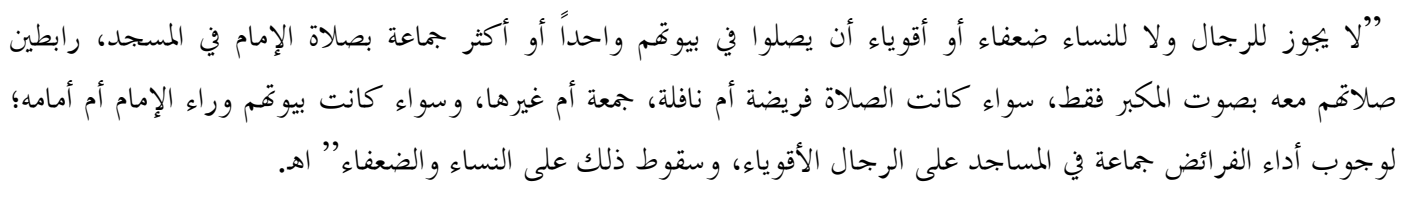

Artinya:

"Tidak boleh para lelaki dan wanita, orang lemah atau yang masih kuat, untuk salat di rumah mereka, baik sendirian maupun berjemaah dengan niat mengikuti imam di masjid, menyambungkan salat mereka dengan salatnya imam melalui perantara pengeras suara saja, baik salat wajib maupun sunah, salat Jumat atau salat lainnya, baik rumahnya berada di belakang imam atau depannya, karena kaum laki-laki yang mampu berkewajiban melakukan salat fardu berjemaah di masjid, tidak wajib bagi kaum wanita dan orang-orang lemah."17

\section{Membaca Mushaf atau HP Ketika Menjadi Imam Salat Tarawih di Rumah}

Para ulama bersepakat disyariatkannya pembacaan Al-Qur'an dalam salat, karena Allah Ta'ala mengatakan:

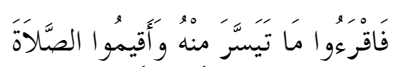

${ }^{15}$ Ali bin Muhammad al-Mawardi, al-Hawi al-Kabir Syarah Mukhtasar al-Muzani, Juz II (Cet. I; Beirut: Dar Kutub Ilmiyah, 1999), h. 343.

${ }^{16}$ Abdullah bin Ahmad bin Quddamah, al-Mugni, Juz II, h. 153.

${ }^{17}$ Lajnah Daimah, Fatawa Lajnah Daimah, Juz VIII (Riyadh: Riasah Idarah al-Buhuts al'Ilmiyyah wal Iftaa) h.214. 
Terjemahnya:

"Bacalah apa yang dimudahkan darinya (Al-Qur'an) dan lakukanlah salat.” (Q.S. al-Muzzammil: 20)

Namun mereka berbeda pandangan mengenai masalah kebolehan membaca dari mushaf saat ibadah salat ke dalam tiga pendapat:

1) Imam Abu Hanifah ${ }^{18}$ berpandangan bahwa jika imam mengimami dengan membaca dari Al-Qur'an, maka salatnya tidak sah baik itu salat wajib dan sunah, dengan alasan:

a. Membawa Al-Qur'an dan membalik-balik kertas dan melihatnya serta memikirkannya untuk memahami, adalah perbuatan yang sangat banyak yang merusak ibadah salat, tetapi dari alasan ini dapat dipahami bahwa dikatakan bahwa: Jika Al-Qur'an diletakkan di hadapannya atau dia membaca apa yang tertulis di mihrab, maka salatnya tetap sah. ${ }^{19}$

b. Dia seolah-olah sedang belajar dari mushaf karena ia membaca darinya, dan hal ini membatalkan salatnya.

c. Membaca Al-Qur'an dari mushaf adalah ibadah yang berdiri sendiri, yang tidak boleh digabung dengan ibadah lainnya seperti ibadah salat. ${ }^{20}$

2) Imam Syafi' ${ }^{21}$ dan Imam Ahmad $^{22}$ berpendapat bahwa diperbolehkan membaca dari mushaf dalam pelaksanaan salat wajib dan sunah. Sebaliknya, ini justru harus dilakukan jika sang imam tidak menghafal surah al-Fatihah misalnya, berdasarkan dalil yang diriwayatkan oleh Imam Bukhari secara mu'allaq dengan periwayatan yang tegas:

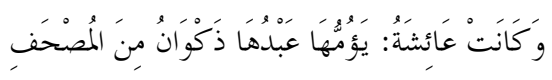

Artinya:

"Adalah Aisyah radhiyallahu anha pernah diimami oleh hamba sahayanya yaitu Dzakwan, dan Dzakwan membaca dari mushaf saat itu." 23

Hadis tersebut dengan jelas menunjukkan bahwa Dzakwan mengimami Aisyah radhiyallahu 'anha dengan membaca dari mushaf, dan hal tersebut h. 201 .

${ }^{18}$ Muhammad bin Ahmad al-Sarakhsi, al-Mabsuth, Juz I (Beirut: Dar al-Ma'rifah, 1993)

19 Muhammad bin Ahmad al-Sarakhsi, al-Mabsuth, Juz I, h.201, dan Abu Bakar bin Mas'ud bin Ahmad al-Kasani, Badāi' al-Sanāi' fi Tartib al-Syarāi', Juz I, h. 236.

${ }^{20}$ Ali bin Abi Bakar al-Marginani, al-Hidayah fi Syarah Bidayah al-Mubtadi, Juz I (Beirut: Dar Ihya Turats) h.63.

${ }^{21}$ Yahya bin Syaraf al-Nawawi, al-Majmu’ Syarah al-Muhadzdzab, Juz IV, h. 95.

${ }^{22}$ Abdullah bin Ahmad bin Quddamah, al-Mugni, Juz I, h. 411.

${ }^{23}$ Muhammad bin Ismail al-Bukhari, Sahih Bukhari, Juz I, h. 140. 
tidak diingkari oleh Aisyah radhiyallahu anha yang menunjukkan penetapan beliau atas kebolehannya, karena jika seandainya tidak boleh maka seharusnya Aisyah radhiyallahu 'anha menegurnya, berdasarkan kaidah:

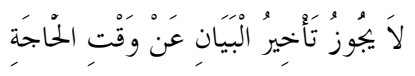

Artinya:

"Tidak diperbolehkan menunda penjelasan kebenaran apabila terdapat hajat untuk mengetahuinya." ${ }^{4}$ Apatah lagi jika dalam persoalan ibadah.

3) Abu Yusuf dan Muhammad dari mazhab Hanafi ${ }^{25}$, dan Malikiyah ${ }^{26}$ yang memandang makruhnya membaca dari mushaf dalam salat wajib, namun boleh dalam salat sunah. Berdasarkan dalil:

a. Riwayat dari Aisyah yang mana beliau diimami oleh Dzakwan dengan membaca Al-Qur'an. ${ }^{27}$ Riwayat ini menunjukkan bolehnya membaca mushaf dalam salat, namun hal ini dimakruhkan karena dapat menjadikan kaum muslimin meninggalkan keutamaan menghapal AlQur'an.

b. Karena melihat Al-Qur'an adalah ibadah, membacanya juga adalah ibadah, dan bergabung dengan ibadah salat sejatinya hal ini tidak membatalkan salat namun hal itu dimakruhkan. ${ }^{28}$

c. Hal ini juga dimakruhkan karena dia menyerupai perbuatan Ahli Kitab yang mana mereka membaca dari kitab dalam doa-doa mereka. ${ }^{29}$

Berdasarkan pada penjelasan di atas maka pendapat yang rajih adalah bolehnya membaca dari mushaf dalam salat sunah, seperti salat tarawih bagi imam yang tidak menghafal Al-Qur'an. Adapun dalam salat wajib maka hukumnya dimakruhkan karena tidak adanya hajat untuk hal tersebut. Apabila terdapat hajat seperti: imam ingin memanjangkan bacaannya pada salat subuh sebagai bentuk pengamalan sunah Nabi, namun hafalannya tidak terlalu banyak, maka boleh baginya untuk membaca dari mushaf. Hukum ini dapat diterapkan baik itu salat tersebut dikerjakan di masjid sebagaimana lazimnya ditemukan dalam bulan Ramadan, ataupun di rumah, karena persoalan yang diperselisihkan

${ }^{24}$ Ibrahim bin Ali bin Yusuf al-Syirazi, al-Luma' fi Ushul al-Fiqh, (Cet. II; Beirut: Dar alKutub al-'Ilmiyyah, 2003) h. 53.

${ }^{25}$ Muhammad bin Ahmad al-Sarakhsi, al-Mabsuth, Juz I (Beirut: Dar al-Ma'rifah, 1993) h. 201 .

${ }^{26}$ Ahmad bin Idris al-Qarafi, al-Dzakhirah, Juz II, (Cet. I; Beirut: Dar al-Garb al-Islamy, 1994) h.408.

${ }^{27}$ Muhammad bin Ismail al-Bukhari, Sahih Bukhari, Juz I, h. 140.

${ }^{28}$ Abu Bakar bin Mas'ud bin Ahmad al-Kasani, Badāi' al-Sanāi' fi Tartib al-Syarāi', Juz I, h. 236 .

${ }^{29}$ Abu Bakar bin Mas'ud bin Ahmad al-Kasani, Badāi' al-Sanāi' fi Tartib al-Syarāi', Juz I, h. 236 . 
oleh ulama dalm masalah ini adalah pembacaan dari mushaf dalam salat, dan bukan tentang tempat pelaksanaan ibadah salat itu.

\section{Bagaimana dengan Membaca Al-Qur'an dari Aplikasi Mushaf di HP Saat Salat Tarawih?}

Tentu saja ini adalah masalah kontemporer yang oleh para ulama menyerupakan masalah ini dengan hukum membaca Al-Qur'an dari mushaf, sehingga hukumnya sama dengan jawaban sebelumnya. Hanya saja perlu diperhatikan, bagi seorang yang hendak membaca Al-Qur' an dari mushaf HP-nya maka sebaiknya ia telah mematikan seluruh jaringan komunikasi HP-nya (telepon dan internet) dan hanya membuka aplikasi mushaf tersebut, agar konsentrasinya tidak terganggu saat membaca. Disarankan agar setiap muslim untuk memperbaiki hubungannya dengan Al-Qur'an, banyak membaca dan menghapalkan ayat-ayat Allah, sehingga ia dapat melakukan apa yang paling afdal yaitu membacakan ayat Allah dari hapalannya saat mengimami kaum muslimin atau keluarga sendiri dalam salat berjemaah. Wallahu a'lam.

\section{KESIMPULAN} berikut:

Berdasarkan penjelasan di atas, dapat disimpulkan beberapa hal sebagai

Pertama, terlepas manakah yang lebih utama apakah salat berjemaah di masjid atau salat di rumah, yang jelas bahwasanya Rasulullah shallallahu 'alaihi wasallam pernah melaksanakannya sendiri di rumah dan pernah juga berjemaah bersama dengan para sahabatnya di masjid. Hal ini menunjukkan bahwa keduaduanya boleh dilakukan, baik berjemaah di masjid atau berjemaah di rumah atau salat sendiri-sendiri di rumah. Kendati demikian, jika berada di suatu daerah yang potensi penyebaran terjangkitnya wabah Covid-19 tinggi dan telah ada imbauan dari pemerintah dan MUI setempat untuk melaksanakan salat tarawih di rumah masing-masing maka dalam kondisi seperti ini yang lebih utama adalah melaksanakan salat tarawih di rumah, baik itu dengan berjemaah bersama dengan anggota keluarga, dan itu yang utama, atau dikerjakan secara sendiri-sendiri.

Kedua, tidak sahnya salat seseorang yang bermakmum mengikuti imam salat jemaah di luar bangunan masjid, dimana para ulama bersepakat bahwa ia harus mendatangi masjid.

Ketiga, bolehnya membaca dari mushaf dalam salat sunah, seperti salat tarawih bagi imam yang tidak menghafal Al-Qur'an. Adapun dalam salat wajib maka hukumnya dimakruhkan karena tidak adanya hajat untuk hal tersebut. Hukum ini juga berlaku bagi seseorang yang hendak membaca Al-Qur'an dengan aplikasi Al-Qur'an di HP. 


\section{DAFTAR PUSTAKA}

Abu Dawud. (1430). Sunan Abi Dawud, Juz II. Cet. I; Dar al-Risalah al'Alamiyah, h. 525.

Al-Bukhari. (1422). Sahih Bukhari, Juz VIII. Cet. I; Dar Tauq al-Najat, h. 6113.

Al-Kasani. (1986). Badāi' al-Sanāi' fi Tartib al-Syarāi', Juz 1. Beirut: Dar Kutub Ilmiyah, h. 541-641.

Al-Marginani. al-Hidayah fi Syarah Bidayah al-Mubtadi, Juz I. Beirut: Dar Ihya Turats, h.63.

Al-Mawardi. (1994). Al-Hawi al-Kabir Syarh Mukhtasar al-Muzani, Juz 2. Beirut: Dar Kutub Ilmiyah, h. 343.

Al-Nawawi. al-Majmu’ Syarah al-Muhadzdzab, Juz III. Dar al-Fikr, h. 492.

Al-Qarafi. (1994). al-Dzakhirah, Juz II. Cet. I; Beirut: Dar al-Garb al-Islamy, h.408.

Al-Sarakhsi. (1993). al-Mabsuth, Juz I. Beirut: Dar al-Ma'rifah, h.201.

Al-Syirazi. (2003). al-Luma' fi Ushul al-Fiqh, Cet. II; Beirut: Dar al-Kutub al'Ilmiyyah, h. 53.

Ibnu Abi Syaibah. (1409). al-Mushannaf, Juz II. Cet. I; Riyadh: Maktabah alRusyd, h. 166.

Ibnu Hajar. (1379). Fathul Bari Syarah Sahih Bukhari, Juz II. Beirut: Dar alMa'rifah, h. 215.

Ibnu Quddamah. (1388). al-Mugni, Juz II. Kairo: Maktabah al-Qahirah, h. 123.

Iskandar, A., Aqbar, K. Kedudukan Ilmu Ekonomi Islam di Antara Ilmu Ekonomi dan Fikih Muamalah: Analisis Problematika Epistemologis. Nukhbatul 'Ulum: Jurnal Bidang Kajian Islam, Vol. 5, No. 2 (2019), h. 88-105.

Lajnah Daimah. Fatawa Lajnah Daimah, Juz VIII. Riyadh: Riasah Idarah alBuhuts al-'Ilmiyyah wal Iftaa, h.214.

Malik. (1994). Al-Mudawwanah al-Kubra, Juz 1. Beirut: Dar Kutub Ilmiyah, h. 175-176.

Muslim. Sahih Muslim, Juz I. Beirut: Dar Ihya al-Turats, h. 539. 